\title{
Birth of the Blanket Protest
}

\author{
Ned Flynn \\ H Block 4, Long Kesh
}

Ned Flynn, from Andersonstown in West Belfast, was nineteen years of age in 1976 when he was sentenced and became the second man to enter the historic blanket protest in the $\mathrm{H}$ blocks. As we commemorate the twentieth anniversary of the beginning of that campaign, he reflects on how the protest started.

Twenty years ago, Britain's three-pronged strategy to break the republican struggle was in full swing, i.e. normalisation, Ulsterisation, and criminalisation. Normalisation involved the British Government portraying the conflict to the international community as one which was well under control, with a degree of normality now evident. Ulsterisation involved the six-county, sectarian militias of the Royal Ulster Constabulary (RUC) and Ulster Defence Regiment (UDR) taking primary control of security, with the British army now playing a secondary back-up role. Criminalisation was a media-orientated policy, overseen by Northern Ireland Office (NIO) officials, that portrayed the republican struggle as acts of criminals, with terms such as 'mafia-type gangsters,' 'godfathers,' 'racketeers,' and 'drug barons' being circulated daily by the media. Futhermore, the struggle was represented as sectarian, and this portrayal was fuelled by British military intelligence who organised Loyalist death squads and even recruited a Military Reaction Force (MRF) within the nationalist community, mercenaries who were ordered to carry out attacks on nationalists and attribute them to loyalists. To reinforce criminalisation, Britain declared that any republican prisoner captured after March 1, 1976 would be classified as a criminal rather than a POW, and as such, would be treated accordingly.

To enhance the success of their three-pronged strategy, the British Government set up a conveyor belt system to remove political opponents and community activists from the streets. It was a quasi-legal alternative to the use of internment without trial which was ended in December 1975 due to international and human rights pressure. The conveyor belt system began in Castlereagh RUC interrogation centre where people perceived as a threat to the state were tortured to extract a false confession. This was later confirmed to Amnesty International by none other than the resident physician, Dr. Irwin. After a long period on remand, the victim was then brought before a Diplock, non-jury court where a single judge appointed by the British Government would blatantly reject the medical evidence of torture and convict on the word 
of the RUC interrogator. The end result was the victim being dispatched to the $\mathrm{H}$ blocks of Long Kesh to serve out his or her sentence.

Like so many other young men and women who entered the jail system in 1976, I was incapable of articulating Britain's cleverly-designed strategy but, as time would tell, the contribution of the men in the H blocks and the women in Armagh jail was to prove crucial in turning Britain's three-pronged strategy on its head and reviving republican morale within the nationalist six counties. However, the cost in terms of sacrifice was high indeed. In the summer of 1976, Crumlin Road jail was overflowing due to the RUC's systematic round up of nationalists. The talk on everyone's lips, besides their own impending 'trial,' was what lay ahead of us when we ended up in the H blocks of Long Kesh. No republican POW incarcerated after the 1st of March had been sentenced yet so we didn't know how Britain was going to enforce their criminalisation policy. While the fear of the unknown was playing on everyone's mind, we were sure of one thing: we were republican POWs, and irrespective of the consequences which lay ahead, there was no way we were going to let the British Government demonise us or our struggle.

In October 1976, three weeks after Kieran Nugent, the first man sentenced, entered the $\mathrm{H}$ blocks, I was sentenced to three years imprisonment. I found myself in the unenviable position of travelling to the $\mathrm{H}$ blocks of Long Kesh in a 'meat wagon' (an armoured lorry) with five loyalist prisoners. While the loyalists were generally chit-chatting amongst themselves on the journey up, I was overburdened with the sense of being all alone, wrapped up in my own thoughts, wondering what the impending welcoming party held for me.

On entering A and B wing of $\mathrm{H} 1$, which housed ordinary criinals, I told the screws there was no way would I wear the prison uniform or conform to prison rules because I was a Republican POW. At this they laughed and told me in a threatening manner that I would change my mind very shortly. From that moment onward, the screws tried every conceivable method the British Government could conjure up to try and dehumanise us into submitting to their criminalisation policy. They moved me to $\mathrm{C}$ and $\mathrm{D}$ wing $\mathrm{H} 1$ which was not in use. I was put into a bare cell, given a blanket to cover myself, and then the screws left without giving me any food or a mattress to lie on. I was in need of a friendly voice to give me some reassurance, so I got up to the door and called out to Kieran Nugent thinking he would be somewhere in these two wings; but, all I heard was my own echo resounding up and down the corridor. I was on my own.

Over the next number of days, the screws kept up the psychological pressure, informing me at every opportunity that I was on my own as Nugent had put the uniform on; but after a few weeks, I found out he was in a cell in A and B wing. As the days went by, I began to lose all track of time as well as weight because they were just giving me the bare minimum to keep me going. However, when they saw that this and the isolation was having no effect, they switched tactics. 
I was taken to the punishment block within the camp where I was charged and sentenced to 14 days loss of remission, 14 days loss of privileges, and three days solitary confinement, which was a bit ironic since I had been in solitary confinement since I entered the blocks and would remain so for the rest of my sentence. The real reason for my move to the punishment block became apparent when a number of screws came into my cell and gave me a beating. All I could do was curl up into a ball and wait until it was over. Undoubtedly, this was one of the lowest points of my time in jail; I was on my own, isolated from my family, freinds, and comrades, and the screws took great delight in informing me that much of the same and more was to come.

From what seemed like an eternity of complete isolation, but which in effect was only about three weeks, I was moved to A and B wing $\mathrm{H} 1$ where six of my comrades, sentenced a few days beforehand, joined Kieran Nugent and myself on what was now called the blanket protest. After my ordeal over the previous three weeks or so, I can only describe the joy of hearing a freindly voice as akin to somebody giving me a million dollars. Sadly the luxury of spending time with my comrades, even if the conversation was conducted between walls, was short-lived. Two days later I was on the move again.

The NIO was obviously desperate to fragment our unity from the inception of the blanket protest and they thought this was best done by singling out the younger members of the protest for specialised treatment in order that the blanket protest would crumble. Therefore myself, Kieran Nugent, and Paul McEnarney, all under 21, were moved to $\mathrm{H} 2$, me to $\mathrm{D}$ wing, Paul to $\mathrm{C}$, and Kieran to B. Once again the administration were hoping that isolation from our comrades would sap our will to continue the blanket protest, and that us breaking would have a domino effect on the rest of our comrades.

Isolation was only one part of their strategy. Inhuman and degrading treatment as well as mental and physical torture were all methods designed to cause the collapse of the protest. Initially, what little food they gave us was brought to the cell by ordinary criminals, but after a week or so, they said if I was not fed, I had to leave the cell naked and go to get it. On one side of the wing, there were ordinary criminals, on the other side, the cells were all empty except for the one I occupied, so in order to get my food, I had to go naked into a canteen full of men. The screws took great pleasure in making lewd remarks about certain parts of my anatomy and they encouraged the criminals to do likewise. At every available opportunity, they paraded us like cattle. For example, every fortnight they forced us to go out to the circle (the central area of the block) naked so that the doctor could examine us and declare us fit to be punished. Picture the scene: on a freezing December morning a naked blanket man forced to stand for thirty minutes in front of seventy criminals and numerous screws; he is blue with cold and shivering from head to foot, yet this so called member of the medical profession declares him fit for anything. The NIO would go to any lengths in order to try and degrade us into capitulating and 
accepting their criminal status. For example, they told us we would be deprived of going to Mass unless we went naked or wore the prison uniform and so it was, that rather than miss the sacraments, we went to Mass naked on Sunday.

As well as the humiliating and degrading treatment, we also had to contend with the physical abuse and the constant threat of it which was worse than the actual beatings. One screw in particular was given a free hand to do as he wished to the blanket men and no one was left unscathed. Any young lad coming onto the blanket was put through a gruesome ordeal. He was always brought up to $\mathrm{H} 2$ at $5: 00 \mathrm{pm}$ when all the screws were in the circle, and when he delcared he was going on the blanket, many of the screws joined in on stripping him naked and beating him senseless.

The deprivation was all encompassing. We were locked up 24 hours a day, put into a bare cell at 8:30 each morning, and moved into a cell with a bed in it at 8:30 that night. We had no books, radios, tobacco, writing material, or anything of that nature; all of these things were confiscated when we went on the blanket. By Christmas 1976, I had been in the Hblocks three months. I did not even know if the outside world knew I existed because I had not seen any of my family as the screws would not let us take visits unless we wore the prison uniform. Our only statutory entitlement was being allowed to write a one-page letter to our families every month, and in return, we were allowed to get one back; but, when I had my first visit eighteen months later, my family told me they had received nothing. It later emerged that the screws ripped our letters up and held back mail from us to give us the impression that we were forgotten.

Christmas 1976 was a very bleak period for the blanket men, but through all the trials and tribulations, we persevered. Our resolve to remain steadfast to our principles and ideals as republican POWs was far greater than the resolve of the British Government to break us.

The blanket protest continued for another five years, escalating into a nowash protest and culminating in the 1981 hunger strike. By that stage, Britain's criminalisation strategy, and indeed its international reputation, lay in tatters. The Republican Movement was resurgent, providing a solid foundation for the further development of the struggle and culminating in the present peace process. As for conditions in the $\mathrm{H}$ blocks, mindful of the sacrifices endured during our jail campaigns, I write this article twenty years on in an environment where we have de facto recognition as POWs and where we have created the opportunities for personal and collective development beyond anything we imagined possible in 1976. 